\title{
PENGARUH AUDIT DELAY, OPINI AUDIT, DAN AUDIT TENURE TERHADAP PERGANTIAN KANTOR AKUNTAN PUBLIK (KAP) PADA PERUSAHAAN MANUFAKTUR YANG TERDAFTAR DI BEI PERIODE 2010-2015
}

\author{
Muhammad Luthfi ${ }^{1}$ \\ luthfi27@gmail.com
}

\section{Dian Apita Sari}

Program Studi Akuntansi,

Fakultas Ekonomi, Universitas Malahayati, Bandar Lampung

\begin{abstract}
.
This reserach aims to analyze the influence of Audit Delay, Opin Audit and Audit Tenure on changes to Public Accounting Firm $(K A P)$ in Indonesia. Some previous research on the change of KAP looks different results.Therefore, another study was conducted to reexamine the theory of the change of KAP.

Data collection method used in this research is purposive sampling, that is sample collection method based on the criteria of the research objectives.

Pursuant to purposive sampling method, total sample obtained in this research is 240 samples from manufacturing company listed in Indonesia Stock Exchange (BEI) during period 2010-2015. Hypothesis testing in this study was done by using logistic regression method (logistic regression) in the application of SPSS 22 program.

The result of the research shows that audit opinion influences significantly to the change of KAP whereas, audit delay and audit tenure does not significantly influence the change of KAP.
\end{abstract}

Keywords: audit opinion, audit delay, audit tenure, Public Accounting Firm.

\section{Latar Belakang}

Perusahaan yang telah go public serta mendaftarkan sahamnya pada Bursa Efek Indonesia (BEI) berkewajiban menerbitkan laporan keuangan perusahaan sesuai dengan standar akuntansi keuangan yang telah diaudit oleh audit independen. Laporan keuangan tersebut merupakan bentuk pertanggungjawaban manajemen perusahaan terhadap para pemegang saham serta pihak-pihak luar yang berkepentingan (stakeholder). Oleh sebab itu, laporan keuangan yang baik harus memenuhi karakteristik kualitatif laporan keuangan, yakni dapat dipahami, 
relevan, keandalan, dan dapat dibandingkan sesuai dengan Kerangka Dasar Penyusunan Penyajian Laporan Keuangan pada PSAK (IAI, 2009).

Akuntan publik atau auditor merupakan pihak independen yang dianggap dapat menilai keandalan dari laporan keuangan yang disajikan oleh perusahaan (Masruroh, 2016). Sering kali terdapat benturan kepentingan antara manajemen perusahaan dengan kepentingan para stakeholde yang menimbulkan potensi terpengaruhnya laporan keuangan dengan kepentingan pribadi pihak manajemen, disisi lain para stakeholder membutuhkan laporan keuangan yang andal dan dapat dipercaya.

Pentingnya peran akuntan publik membuat kebutuhan akan jasa dari akuntan publik semakin banyak dibutuhkan, terlebih lagi dengan berkembangnya perusahaan publik. Meningkatnya kebutuhan jasa audit berpengaruh terhadap perkembangan profesi akuntan publik di Indonesia dan menimbulkan persaingan antara KAP yang satu dengan lainnya, sehingga memungkinkan perusahaan untuk berpindah dari satu KAP ke KAP lain (Prahartari, 2013)

Masa perikatan audit yang lama menyebabkan perusahaan merasa nyaman dengan hubungan yang terjalin selama ini, antara auditor (KAP) dengan pihak manajemen perusahaan dimana, mencapai tahap auditor akan terikat secara emosional dan mengancam independensinya. Menurut Sumarwoto (2006) dalam Wijayani (2011) terdapat keraguan mengenai independensi Auditor ketika Auditor dan klien memiliki masa hubungan kerja yang cukup lama. Penelitian tersebut didukung dengan penelitian yang dilakukan oleh Diaz (2009) dalam Wijayani (2011) bahwa masa hubungan kerja yang antara Auditor dan klien menyebabkan timbulnya rasa "nyaman" yang terjalin antara keduanya.

Hal tersebut terjadi ketika Enron Corporation yang diaudit oleh Kantor Akuntan Publik (KAP) Arthur Andersen selama 16 tahun sejak 1985, yang menyebabkan tidak independensinya Kantor Akuntan Publik tersebut karena Arthur juga menyediakan jasa non-audit (memberikan jasa akuntansi) bagi Enron. Banyak pihak berpendapat bahwa hal ini disebabkan akibat adanya hubungan kerja yang panjang antara KAP dan klien yang memungkinkan menciptakan suatu resiko excessive familiarity (berlebihnya keakraban) yang dapat mempengaruhi 
obyektivitas dan independensi KAP. Kegagalan KAP Arthur Anderson ini melahirkan The Sarbanes-Oxley Act (SOX) pada tahun 2002. SOX ini dikeluarkan dan dipergunakan oleh banyak negara untuk memperbaiki struktur pengawasan terhadap KAP, yaitu dengan menerapkan rotasi KAP maupun auditor (Masruroh, 2016).

Menanggapi kasus tersebut pada tahun 2003 Indonesia mengeluarkan peraturan mengenai auditor switching yaitu Keputusan Menteri Keuangan Nomor 359/KMK.06/2003 tanggal 21 Agustus 2003 pasal 2 tentang “Jasa Akuntan Publik" (perubahan atas Keputusan Menteri Keuangan Nomor 423/KMK.06/2002). Peraturan ini menyatakan bahwa pemberian jasa audit umum atas laporan keuangan dari suatu entitas dapat dilakukan oleh KAP paling lama 5 (lima) tahun buku berturut-turut dan oleh seorang Auditor paling lama 3 (tiga) tahun buku berturut-turut. Perusahaan yang masa penugasan audit telah mencapai lima tahun pada tahun 2003 masih dapat melaksanakan audit umum atas laporan keuangan entitas tersebut sampai dengan tahun buku 2003. Adanya rotasi ini KAP diharapkan dapat tetap mempertahankan independensi dalam melaksanakan proses auditnya (Prastiwi dan Wilsya, 2009).

Selanjutnya peraturan tersebut diperbaharui dengan dikeluarkannya Peraturan Menteri Keuangan Nomor 17/PMK.01/2008 tentang “Jasa Akuntan Publik" yang memiliki dua perubahan. Perubahan yang pertama, mengenai pemberian jasa audit umum atas laporan keuangan menjadi paling lama 6 (enam) tahun buku berturut-turut (pasal 3 ayat 1) dan oleh seorang Auditor paling lama 3 (tiga) tahun buku berturut-turut. Perubahan yang kedua, Auditor atau KAP boleh memberikan jasa audit umum atas laporan keuangan klien setelah 1 (satu) tahun buku tidak memberikan jasa audit umum kepada klien tersebut (pasal 3 ayat 2).

Auditor switching sendiri dapat terjadi secara mandatory (wajib) dan voluntary (sukarela). Auditor switching secara mandatory terjadi karena peraturan yang mengharuskan perusahaan melakukan pergantian KAP atau Auditor secara berkala. Sedangkan auditor switching secara voluntary terjadi karena perusahaan secara suka rela mengganti KAP atau Auditor yang memberikan jasa audit umum kepadanya. Jika terjadi pergantian KAP atau Auditor diluar ketentuan yang telah ditetapkan akan menimbulkan kecurigaan mengenai faktor yang menyebabkan pergantian auditor tersebut oleh para investor. Perusahaan yang mengalami pergantian auditor secara voluntary dimungkinkan sedang dalam kondisi yang 
tidak normal sehingga perlu diteliti faktor yang menyebabkan perusahaan tersebut melakukan pergantian auditor (Masruroh, 2016).

Salah satu faktornya dalam hal Audit Delay. Audit delay adalah lamanya waktu yang dibutuhkan oleh auditor dalam menghasilkan laporan audit atas laporan keuangan perusahan terhitung dari tanggal tutup tahun sampai tanggal opini audit diserahkan dan ditandatangi (Robbitasari \& Wiratmaja, 2013). Lamanya audit delay yang terjadi akan menyebabkan laporan keuangan terlambat diberikan kepada BAPEPAM-LK dan laporan keuangan terlambat dapat diumumkan kepada masyarakat umum. Keterlambatan tersebut akan menimbulkan persepsi investor bahwa perusahaan sedang mengalami kondisi yang kurang baik, sehingga dapat mempengaruhi pergerakan IHSG (Indeks Harga Saham Gabungan). Audit delay mempengaruhi keputusan yang dilakukan oleh investor karena mereka menginginkan informasi mengenai keberlangsungan usaha perusahaan untuk keputusan berinvestasi. Apabila terjadi audit delay maka akan mempengaruhi perusahaan dalam memperoleh dana investasi dari investor sehingga kemungkinan perusahaan mengganti auditornya (Ardianingsih, 2014).

Faktor lainnya opini audit. Opini ini yang dikeluarkan oleh auditor setelah selesai mengaudit laporan keuangan suatu perusahaan. Opini audit sangat penting dalam proses audit karena opini tersebut merupakan informasi utama yang dapat diinformasikan kepada pemakai informasi tentang apa yang dilakukan auditor dan kesimpulan yang diperolehnya (Wijaya, 2013). Opini Wajar Tanpa Pengecualian tidak sekedar menjadi indikator keberhasilan kinerja sebuah entitas bisnis, pemerintah, atau pun kelompok tertentu, tapi juga sudah menjadi standar reputasi publik dalam upaya meningkatkan citra positif mereka dalam pengelolaan dan pertanggungjawaban keuangan. Perusahaan yang mendapatkan opini wajar tanpa pengecualian cenderung untuk tidak mengganti auditornya.

Audit tenure juga memiliki pengaruh terhadap pergantian KAP. Lamanya jangka waktu pemberian jasa audit terhadap klien tertentu oleh suatu KAP juga disebut audit tenure (Shockley, 1981 dalam Astrini, 2013). Ketentuan mengenai audit tenure ini dijelaskan dalam Keputusan Menteri Republik Indonesia Nomor 359/KMK.06/2003 pasal 2, selanjutnya peraturan tersebut diperbaharui dengan 
dikeluarkannya Peraturan Menteri Keuangan Nomor 17/PMK.01/2008 tentang “Jasa Akuntan Publik". Audit tenure yang panjang dapat menyebabkan kulitas dari kompetensi kerja auditor cenderung menurun secara signifikan dari waktu ke waktu dan dapat menimbulkan persepsi bahwa auditor sulit untuk bersikap independen, karena kemungkinan adanya keterakitan yang bersifat pribadi yang dinilai dapat mengganggu independensi auditor (Astrini, 2013). Hal itulah yang menjadikan audit tenure sebagai faktor yang juga mempengaruhi pergantian KAP.

Berdasarkan latar belakang tersebut, tujuan dari penelitian ini untuk melakukan penelitian kembali terhadap konsistensi hasil dengan penelitian sebelumnya, dengan membuktikan faktor Audit Delay, Opini Audit dan Audit Tenure sebagai variabel independennya. Populasi yang digunakan yakni perusahaan manufaktur yang terdaftar di Bursa Efek Indonesia (BEI) karena, menurut Susanti (2014), perusahaan tersebut memiliki jumlah perusahaan go public terbesar di BEI sehingga diharapkan dapat menjelaskan keseluruhan dari populasi. Penelitian ini juga mengambil sampel 6 tahun terakhir, yaitu pada tahun 2010-2015, diharapkan hasil dari penelitian ini dapat mencerminkan kondisi terbaru dari objek penelitian. Untuk pengamatan selama 6 tahun berturut-turut, ini dikarenakan sesuai Peraturan Menteri Keuangan Nomor 17/PMK.01/2008 tentang "Jasa Akuntan Publik" dengan harapan penelitian ini mendapatkan hasil yang lebih akurat. Penelitian ini mengambil judul "Pengaruh Audit Delay, Opini Audit dan Audit Tenure Terhadap Pergantian Kantor Akuntan Publik (KAP) Pada Perusahaan Manufaktur Yang Terdaftar di BEI Periode 2010-2015”.

\section{Kajian Pustaka}

\section{Teori Agensi}

Teori keagenan merupakan grand theory dalam penelitian ini. Hubungan agensi muncul ketika satu orang atau lebih (principal) mempekerjakan orang lain (agent) untuk memberikan suatu jasa, kemudian mendelegasikan wewenang pengambilan keputusan kepada agen tersebut. Penyebab timbulnya masalah agensi ini yaitu adanya konflik kepentingan antara principal dan agent, akibat tidak bertemunya tujuan yang sejalan diantara mereka (Jensen dan Meckling, 
1976). Dalam teori agensi, auditor independen berperan sebagai penengah kedua belah pihak (agent dan principal) yang berbeda kepentingan. Auditor independen juga berfungsi untuk mengurangi biaya agensi yang timbul dari perilaku mementingkan diri sendiri yang dilakukan oleh manajer. Tingkat biaya tersebut bervariasi pada organisasi, tergantung pada variabel seperti ukuran perusahaan, dan kepemilikan saham manajemen. Dalam informasi ekonomi, pemilihan auditor yang dapat dipercaya digunakan sebagai sinyal kejujuran manajemen (Dopuch dan Simunic, 1980; Dopuch dan Simunic, 1982 dalam Nasser et al., (2006).

\section{Pergantian Kantor Akuntan Publik (KAP)}

Pergantian KAP merupakan perpindahan KAP yang dapat terjadi pada suatu perusahaan. Pergantian KAP bisa dibedakan menjadi dua jenis yaitu pergantian yang bersifat peraturan (mandatory) dan yang bersifat sukarela (voluntary). Audit yang dilaksanakan oleh auditor pada laporan keuangan suatu perusahaan memiliki tujuan untuk memberikan opini atas kewajaran laporan keuangan tersebut. Pemberian opini yang dilakukan auditor dapat mengurangi timbulnya ketidaksamaan penerimaan informasi antara manajemen dan pihak stakeholders karena memungkinkan pihak luar untuk memverifikasi validitas laporan keuangan. Perusahaan yang memperoleh opini diluar opini wajar tanpa pengecualian kemungkinan besar akan melakukan penggantian auditor untuk mencari auditor yang diharapkan nantinya akan memberikan opini yang lebih baik (Mahantara, 2013).

\section{Audit Delay}

Audit Delay atau yang biasa disebut Audit Report Lag adalah jangka waktu dari tanggal penutupan tahun buku hingga tanggal diterbitkannya laporan audit (Hossain dan Taylor, 1998 dalam Janartha Suprapto 2016). Waktu yang dibutuhkan oleh auditor untuk menghasilkan laporan audit atas kinerja laporan keuangan suatu perusahaan disebut audit delay (Puspitasari dan Latrini, 2014). Semakin panjang suatu audit report lag, maka akan mempengaruhi ketepatan waktu dalam publikasi informasi laporan keuangan auditan dan memberikan 
dampak buruk bagi perusahaan. Berdasarkan keputusan Ketua BAPEPAM Nomor Kep-36/PM/2003 laporan keuangan perusahaan yang telah diaudit dan ditandatangani oleh auditor independen harus sudah disampaikan kepada BAPEPAM tidak lebih dari 90 hari dari tahun tutup buku perusahaan.

\section{Opini Audit}

Opini audit merupakan opini yang dikeluarkan oleh auditor setelah selesai mengaudit laporan keuangan suatu perusahaan. Opini yang terdapat dalam laporan audit sangat penting dalam proses audit atapun proses atestasi lainnya karena opini tersebut merupakan informasi utama yang dapat diinformasikan kepada pemakai informasi tentang apa yang dilakukan auditor dan kesimpulan yang diperolehnya (Wijaya, 2013).

\section{Audit Tenure}

Audit tenure adalah masa perikatan audit dari KAP dalam memberikan jasa audit terhadap kliennya. Ketentuan mengenai audit tenure telah dijelaskan dalam Peraturan Menteri Keuangan Republik Indonesia Nomor 17/PMK.01/2008 tentang "Jasa Akuntan Publik". Perubahan yang dilakukan di antaranya adalah, pertama, pemberian jasa audit umum menjadi 6 (enam) tahun berturut-turut oleh KAP dan 3 (tiga) tahun berturut-turut oleh akuntan publik kepada satu klien yang sama (pasal 3 ayat 1). Kedua, akuntan publik dan KAP boleh menerima kembali penugasan setelah 1 (satu) tahun buku tidak memberikan jasa audit kepada klien yang di atas (pasal 3 ayat 2 dan 3 ).

\section{Tujuan dan Manfaat}

\section{Tujuan Penelitian}

Tujuan yang ingin dicapai dari penelitian ini adalah:

1. Untuk menguji apakah Audit Delay berpengaruh terhadap keputusan untuk melakukan pergantian Kantor Akuntan Publik (KAP) oleh klien?

2. Untuk menguji apakah Opini Audit berpengaruh terhadap keputusan untuk melakukan pergantian Kantor Akuntan Publik (KAP) oleh klien? 
3. Untuk menguji apakah Audit Tenure berpengaruh terhadap keputusan untuk melakukan pergantian Kantor Akuntan Publik (KAP) oleh klien?

4. Untuk menguji apakah Audit Delay, Opini Audit dan Audit Tenure berpengaruh terhadap keputusan melakukan pergantian Kantor Akuntan Publik (KAP) oleh klien?

\section{Manfaat Penelitian}

Manfaat dari penelitian ini adalah:

1. Bagi profesi Akuntan Publik. Menjadi bahan informasi pada profesi akuntan publik tentang praktik auditor switching yang dilakukan perusahaan.

2. Bagi Regulator. Menjadi salah satu sumber bagi pembuat regulasi yang berkenaan dengan praktek perpindahan KAP oleh perusahaan go public.

3. Bagi Akademisi. Hasil penelitian ini diharapkan dapat memberikan pandangan terhadap pengembangan audit khususnya mengenasi auditor switching.

4. Bagi peneliti selanjutnya. Penelitian ini sebagai sumber referensi dan informasi untuk memungkinkan penelitian selanjutnya mengenai pembahasan auditor switching.

\section{Metode Penelitian}

Populasi penelitian ini adalah 141 perusahaan manufaktur terdaftar di BEI yang tidak delisting atau relisting dalam kurun waktu 2010-2015. Hal ini dikarenakan perusahaan manufaktur memiliki jumlah perusahaan go public terbesar di BEI sehingga diharapkan dapat menjelaskan keseluruhan dari populasi (Susanti, 2014). Pengambilan sampel dalam penelitian ini dilakukan dengan menggunakan purposive sampling method, yaitu penentuan sampel atas dasar kesesuaian karakteristik dan kriteria tertentu.

Adapun kriteria dalam pemilihan sampel, sebagai berikut:

1. Perusahaan manufaktur yang terdaftar di BEI menerbitkan laporan keuangan yang telah diaudit oleh auditor independen secara lengkap selama periode tahun 2010-2015. 
2. Melakukan pergantian KAP minimal 1 (satu) kali pada periode 2010-2015. Dimungkinkan perusahaan melakukan pergantian KAP lebih dari 1 (satu) kali pada periode pengamatan.

3. Mengandung informasi yang lengkap yang mencakup semua definisi operasional penelitian, yaitu: informasi tentang Audit Delay, Opini Audit dan Audit Tenure.

Berdasarkan kriteria diatas maka perusahaan yang memenuhi syarat dalam penelitian ini yaitu sebanyak 40 perusahaan, selama 6 (enam) tahun publikasi laporan keuangan perusahaan sehingga jumlah data yang digunakan sebanyak 240 data penelitian.

\section{Operasional Variabel}

\begin{tabular}{|l|l|l|l|c|}
\hline $\begin{array}{l}\text { N } \\
\text { o. }\end{array}$ & Variabel & $\begin{array}{c}\text { Jenis } \\
\text { Variabel }\end{array}$ & \multicolumn{1}{|c|}{ Indikator } & $\begin{array}{c}\text { Skala } \\
\text { Pengukuran }\end{array}$ \\
\hline 1. & $\begin{array}{l}\text { Pergantian } \\
\text { KAP }\end{array}$ & Dependen & $\begin{array}{l}\text { Variabel dummy, nilai 1 diberikan } \\
\text { jika perusahaan melakukan } \\
\text { pergantian KAP, dan 0 untuk } \\
\text { perusahaan yang tidak melakukan } \\
\text { pergantian KAP. }\end{array}$ & Nominal \\
\hline 2. & Audit Delay & Independen & $\begin{array}{l}\text { Variabel dummy, nilai 1 diberikan } \\
\text { jika perusahaan terlambat } \\
\text { menyampaikan laporan keuangan } \\
\text { dan nilai 0 diberikan jika perusahaan } \\
\text { menyampaikan laporan keuangan } \\
\text { tepat waktu. }\end{array}$ & Nominal \\
\hline 3. & Opini Audit & $\begin{array}{l}\text { Variabel dummy, nilai 1 diberikan } \\
\text { jika perusahaan menerima opini } \\
\text { selain wajar tanpa pengecualian } \\
\text { (WTP), dan 0 untuk perusahaan yang } \\
\text { menerima opini WTP. }\end{array}$ & Nominal \\
\hline 4. & $\begin{array}{l}\text { Audit } \\
\text { Tenure }\end{array}$ & Independen & $\begin{array}{l}\text { Menjumlah masa perikatan audit } \\
\text { sebelum auditor berpindah dalam } \\
\text { satuan tahun. }\end{array}$ & Interval \\
\hline
\end{tabular}




\section{Hasil dan Pembahasan}

\section{Uji Multikolonieritas}

Berdasarkan hasil uji multikolineritas nilai Tolerance menunjukkan tidak ada variabel independen yang memiliki nilai Tolerance kurang dari 0,10 yang berarti tidak ada kolerasi antar variabel independen yang nilainya lebih dari $95 \%$. Hal ini juga dibuktikan dengan nilai VIF dari setiap variabel independen tidak ada yang lebih dari 10. Jadi, dapat disimpulkan bahwa tidak terjadi multikolinearitas antar variabel independen dalam model regresi.

\section{Pengujian Hipotesis}

Berdasarkan hasil pengujian terhadap koefisien regresi menghasilkan model berikut ini

$$
Y=19,623+0.001 X_{1}+1.022 X_{2}-19.827 X_{3}
$$

Hal ini menunjukkan bahwa variabel $\mathrm{X}_{1}$ (Audit Delay) siginifikan pada 0,954, variabel $\mathrm{X}_{2}$ (Opini Audit) tidak signifikan pada 0,016, variabel $\mathrm{X}_{3}$ (Audit Tenure) tidak signifikan pada 0,992. Dari persamaan hasil analisis regresi logistik dapat dilihat bahwa pergantian KAP secara positif dipengaruhi oleh $\mathrm{X}_{1}$ (Audit Delay). Sedangkan secara negatif dipengaruhi oleh $\mathrm{X}_{2}$ (Opini Audit) dan $\mathrm{X}_{3}($ Audit Tenure).

\section{Pembahasan}

Varibel Audit Delay menunjukkan koefisien regresi positif sebesar 0.001 dengan tingkat signifikan sebesar 0,954 yang artinya lebih besar dari $\alpha=0,05$. Hal itu menunjukkan hipotesis pertama tidak berhasil didukung atau $\mathrm{H}_{\mathrm{a}}$ ditolak dan $\mathrm{H}_{0}$ diterima karena tingkat signifikansi lebih besar dari 0,05. Penelitian ini tidak mendukung adanya pengaruh antara audit delay dengan keinginan perusahaan dalam mengganti KAP, dengan kata lain banyak perusahaan manufaktur yang terdaftar di BEI periode 2010-2015 tidak melakukan pergantian KAP meskipun auditor terlambat menyampaikan laporan keuangan. 
Variabel Opini Audit menunjukkan koefisien regresi positif sebesar 1,022 dengan tingkat signifikan sebesar 0,016 yang artinya lebih kecil dari $\alpha=0,05$. Hal ini menunjukkan bahwa hipotesis kedua berhasil didukung atau $\mathrm{H}_{\mathrm{a}}$ diterima dan $\mathrm{H}_{0}$ ditolak karena tingkat signifikansi lebih kecil dari 0,05. Penelitian ini mendukung adanya pengaruh antara opini audit dengan keinginan perusahaan dalam mengganti KAP mereka, dengan kata lain perusahaan yang mendapatkan opini wajar tanpa pengecualian cenderung untuk tidak mengganti auditornya.

Variabel Audit Tenure menunjukkan koefisien regresi negatif sebesar 19,827 dengan tingkat signifikansi sebesar 0,992 yang artinya lebih besar dari $\alpha=$ 0,05. Hal itu menunjukkan hipotesis ketiga tidak berhasil didukung atau $\mathrm{H}_{\mathrm{a}}$ ditolak dan $\mathrm{H}_{0}$ diterima karena tingkat signifikansi lebih besar dari 0,05. Penelitian ini tidak mendukung adanya pengaruh antara audit tenure dengan keinginan perusahaan dalam mengganti KAP, dengan kata lain banyak perusahaan manufaktur yang terdaftar di BEI periode 2010-2015 yang melakukan pergantian KAP diluar ketentuan audit tenure.

\section{Simpulan dan Saran}

Berdasarkan penelitian yang telah dilakukan maka didapatkan beberapa hasil penelitian dimana, Variabel Audit Delay tidak berpengaruh terhadap pergantian KAP pada perusahaan manufaktur yang terdaftar di BEI , dengan nilai signifikansi sebesar 0,954. Varibel Opini Audit berpengaruh terhadap pergantian KAP pada perusahaan manufaktur yang terdaftar di BEI, dengan nilai signifikansi sebesar 0,016. Variabel Audit Tenure tidak berpengaruh terhadap pergantian KAP pada perusahaan manufaktur yang terdaftar di BEI, dengan nilai signifikansi 0,992. Penelitian ini juga mendukung hipotesis pertama bahwa variabel Audit Delay, Opini Audit dan Audit Tenure berpengaruh secara simultan dengan nilai signifikansi 0,000.

Penelitian mengenai pergantian KAP dimasa yang akan datang diharapkan mampu memberikan hasil penelitian yang lebih berkualitas dengan memperluas sampel penelitian dengan mempertimbangkan penggunaan seluruh perusahaan yang terdaftar di BEI sebagai populasi penelitian, mempertimbangkan beberapa 
variabel independen lain yang tidak diuji dalam penelitian ini seperti, karakteristik corporate governonce, pergantian dewan komisaris, kepemilikan institusional dan sebagainya yang mungkin dapat mempengaruhi pergantian KAP untuk meningkatkan pengetahuan mengenai pergantian KAP di Indonesia. Penelitian ini memiliki keterbatasan yaitu pemilihan objek penelitian hanya menggunakan perusahaan sektor manufaktur yang terdaftar di BEI pada periode 2010-2015 dan hanya menguji pengaruh variabel audit delay, opini audit dan audit tenure terhadap pergantian KAP.

\section{Daftar Pustaka}

Ardianingsih, A. 2014. Pengaruh Audit Dalay dan Ukuran KAP Terhadap Audit Switching: Kajian dari Sudut Pandang Klien. Pena Jurnal Ilmu Pengetahuan dan Teknologi.

Astrini, Novia Retno. 2013. Analisis Faktor-Faktor Yang Mempengaruhi Perusahaan Melakukan Auditor Switching Secara Voluntary. Semarang: Jurnal Akuntansi Fakultas Ekonomi dan Bisnis Universitas Diponogoro.

Ikatan Akuntan Indonesia. 2009. "Pernyataan Standar Akuntansi Keuangan Revisi 2009". Jakarta: IAI.

Janartha, I Wayan Pion dan Bambang Suprasto H. 2016. Pengaruh Ukuran Perusahaan, Keberadaan Komite Audit dan Leverage terhadap Audit Delay. E-Jurnal Akuntansi Universitas Udayana Vol.16.3, pp.2374-2407.

Jensen, Michael C., and Meckling, William H.1976. Theory of the Firm: Managerial Behavior, Agency Costs and Ownership Structure. Journal of Financial Economics, October, 1976, V. 3, No. 4, pp. 305-360..

Mahantara, A.A Gede Widya. 2013. Faktor-Faktor Yang Memengaruhi Pergantian Kantor Akuntan Publik Pada Perusahaan Yang Terdaftar di Bursa Efek Indonesia. Mataram: Jurnal Fakultas Ekonomi Universitas Udayana.

Masruroh, Farida. 2016. Pengaruh Pergantian Manajemen, Kesulitan Keuangan, Ukuran KAP dan Audit Delay Terhadap Auditor Switching. Yogyakarta: Jurnal Fakultas Ekonomi Universitas Negeri Yogyakarta

Menteri Keuangan, 2002. Keputusan Menteri Keuangan Nomor: 423/KMK.06/2002 tentang “Jasa Akuntan Publik”. Jakarta. 
Menteri Keuangan, 2003, Keputusan Menteri Keuangan Nomor 359/KMK.06/2003 tentang “Jasa Akuntan Publik". Artikel ini diakses tanggal $18 \quad$ Desember 2016, dari http://www.sjdih.kemenkeu.go.id/fullText/2003/359 KMK.06 2003Kep.ht $\underline{\mathrm{m}}$

Menteri Keuangan. 2008. Peraturan Menteri Keuangan Republik Indonesia Nomor 17/PMK.01/2008 pasal 3 tentang "Jasa Akuntan Publik”. Jakarta.

Nasser, A. T. A., Emelin A. W., Sharifah N. F. S. M. N., dan Mohammad H. 2006. Auditor-Client Relationship: The Case of Audit tenure and Auditor Switching in Malaysia. Managerial Auditing Journal, Vol. 21, No. 7, pp. 724-737.

Prastiwi, Andri dan Frenawidayuarti Wilsya. 2009. Faktor-Faktor Yang Mempengaruhi Pergantian Auditor: Studi Empiris Perusahaan Publik di Indonesia. :Jurnal Dinamika Akuntansi, Vol. 1, No. 1, pp. 62-75.

Robbitasari, A.P., \& Wiratmaja, I. D. 2013. Pengaruh Opini Audit Going Concern, Kepemilikan Institusional dan Audit Delay pada Voluntary Auditor Switching. E-Jurnal Akuntansi Universitas Udayana.

Surat Keputusan Ketua BAPEPAM. 2003. Kewajiban Penyampaian Laporan Keuangan Berkala Nomor: KEP-36/PM/2003. Badan Pengawas Pasar Modal, Indonesia.

Susanti, Ika Silviana. 2014. Faktor-Faktor Yang Berpengaruh Terhdap Auditor Switching. Semarang: Universitas Diponogoro.

Wijaya, R.M Aloysius Pangky. 2013. "Faktor-Faktor yang Mempengaruhi Pergantian Auditor Oleh Klien”. Malang: Jurnal Akuntansi Fakultas Ekonomi dan Bisnis Universitas Brawijaya.

Wijayani, Evi Dwi. 2011. Faktor-Faktor yang Mempengaruhi Perusahaan di Indonesia Melakukan Auditor Switching. Skripsi. Semarang: Universitas Diponegoro. 